\title{
Effect of Fertilizer Application on Phytoremediating Potentials of Euphorbia heterophylla, Axonopus compressus, Emilia coccinea and Scoparia dulcis against $\mathrm{Hg}^{2+}, \mathrm{Pb}^{2+}, \mathrm{Cd}^{2+}$ and $\mathrm{As}^{3+}$
}

\author{
CHIGOZIE JOHN ONYINYE ANARADO', CHARITY EBERE ANARADO*1, \\ FRANCIS CHISOM NWAJIDE ${ }^{1}$, AUGUSTINE OBIORA ${ }^{1}$, VINNA DAN CHUKWUMA ${ }^{1}$, \\ and IJEOMA LILIAN ANARADO ${ }^{1}$
}

\author{
1'Department of Pure and Industrial Chemistry, Nnamdi Azikiwe University, P.M.B. 5025, \\ Awka, Anambra State, Nigeria. \\ ${ }^{*}$ Corresponding author E-mail: ce.anarado@unizik.edu.ng
}

http://dx.doi.org/10.13005/ojc/360317

(Received: May 05, 2020; Accepted: June 15, 2020)

\begin{abstract}
Fertilizer application has gained much attention because not only has it been increasing crop yield (improving the economy of the farmers), but also been increasing/decreasing heavy metals uptake by many plants. In this study, four non-edible African plants-Euphorbia heterophylla, Axonopus compressus, Emilia coccinea and Scoparia dulcis were used to examine the effect of fertilizer (organic manure and Nitrogen Phosphorus Potassium (NPK) fertilizer) application on uptake of $\mathrm{Pb}, \mathrm{Cd}, \mathrm{Hg}$ and As by the plants. The seedlings of the plants were collected, planted and inoculated with $0.1 \mathrm{M}$ solutions of the salts, buffer 7,Organic manure and NPK fertilizers. Plant parts were harvested after 14 weeks of inoculation, washed, air-dried, ashed, digested and analyzed for the presence of the four metal ions. The results showed increase in $\mathrm{pH}$ decreased the absorption of $\mathrm{Pb}, \mathrm{Cd}, \mathrm{Hg}, \mathrm{As}$ by A. compressus and $\mathrm{S}$. dulcis. Organic manure application at $\mathrm{pH}$ of 6.3 increased the uptake of; $\mathrm{Pb}$ by $A$. compressus and E. coccinea. At pH of 7, organic manure application increased the uptake of; $\mathrm{Pb}$ by $E$. heterophylla and $A$. compressus. Application of NPK fertilizer at $\mathrm{pH}$ of 6.3 increased the uptake of; $\mathrm{Pb}$ by $A$. compressus and $\mathrm{S}$. dulcis. At $\mathrm{pH}$ of 7 , NPK fertilizer application increased the absorption of; $\mathrm{Pb}$ and $\mathrm{Cd}$ by all the plants, $\mathrm{Hg}$ by $A$. compressus, As by $\mathrm{E}$. coccinea and $\mathrm{S}$. dulcis. Most of $\mathrm{Pb}$ uptake were found in the roots showing that the plants can be used to phytostabilize the metal ion. Though As was phytotoxic, it was the highest absorbed among the four and E. coccinea could be used as an arsenic hyperaccumulator.
\end{abstract}

Keywords: Phytoremediation, Fertilizers, Euphorbia heterophylla, Axonopus compressus,

INTRODUCTION

Environmental pollution which has been present from the very beginning of life, but today, it is reaching worrying proportions worldwide that threatens the survival of mankind ${ }^{1,2}$. Soil is the fundamental foundation of our agricultural resources, food security, global economy and environmental

This is an Open Access article licensed under a Creative Commons license: Attribution 4.0 International (CC- BY). Published by Oriental Scientific Publishing Company @ 2018

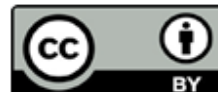


quality. With the development of urbanization and industrialization, soils have become increasingly polluted by heavy metals and organic pollutants ${ }^{3}$. Soil contamination is defined as the change in the soil properties due to accumulation and build-up in soils of harmful substances including toxic compounds ${ }^{4}$. Soils may also be contaminated by the accumulation of heavy metals and metalloids through emissions from the rapidly expanding industrial areas, mine tailings, disposal of high metal wastes, leaded gasoline, paints, land application of fertilizers, animal manures, sewage sludge, pesticides, wastewater irrigation, coal combustion residues, spillage of petrochemicals, and atmospheric deposition ${ }^{5}$. Heavy metals are those metals with specific density of more than $5 \mathrm{~g} / \mathrm{cm}^{3}$ which are detrimental to the environment and anything that is beneficial to the environment ${ }^{6}$. Heavy metals occur as natural constituents of the earth crust, and are persistent environmental contaminants since they cannot be degraded by chemical method but could be evacuated by physical method ${ }^{7,8}$. Some examples of the heavy metals include lead, cadmium, mercury, arsenic, copper, nickel, zinc and chromium ${ }^{9}$. Pollution of the environment by heavy metals has been a global problem and the clean up using the common engineering methods being very expensive ${ }^{10}$. Plants have shown to have the ability of absorbing both essential elements ${ }^{11,12,13}$ and heavy metals from the soil. Phytoremediation which is cheap and environmentally friendly is a process that uses various types of plants to remove, transfer, stabilize, and/or destroy pollutants in the soil, and water ${ }^{14,15}$, and includes several processes namely, phytoextraction, phytodegradation, rhizofiltration, phytostabilization and phytovolatilization ${ }^{16}$. Phytoextraction is contaminant uptake by the root with subsequent accumulation above ground portion of a plant. It is a contaminant removal process use for some heavy metals and metalloids like $\mathrm{Pb}, \mathrm{Cd}, \mathrm{As}$, $\mathrm{Se}, \mathrm{Hg}, \mathrm{Ni}, \mathrm{Co}, \mathrm{Zn}$, etc ${ }^{17}$. Phytostabilization involves the establishment of a plant cover on the surface of the contaminated sites with the aim of reducing the translocation of pollutants and subsequent accumulation by roots ${ }^{18}$. Phytovolatilization is extraction and release of elements to atmosphere in the form of gas compounds and it is important for mercury and arsenic ${ }^{19}$. Phytotransformation/ phytodegradation process is the breakdown of pollutants taken up by plants through metabolic processes within the plant or the breakdown of contaminants externally to the plant through the effect of compounds produced by the plants ${ }^{20}$. In the previous works, various plants have been used in absorbing pollutants such as lead, cadmium, zinc, cobalt, chromium, arsenic, and various radionuclides from soils $21,22,23,24,25,26,27,28,29$. It has been reported that Long-term use of excessive chemical fertilizers and organic manures in the bare vegetable field and the greenhouse vegetable field contributed to the accumulation heavy metals in the soils ${ }^{30}$. Various researchers have reported that fertilizer application increased the uptake of cadmium, arsenic, mercury and lead from the soil by some plants ${ }^{31,32,33,34,35,36,37,38,39}$.

The aim of this work is to investigate the effect of organic manure and NPK fertilizer applications on uptake of $\mathrm{Pb}^{2+}, \mathrm{Cd}^{2+}, \mathrm{Hg}^{2+}$, and $\mathrm{As}^{3+}$ by some non-edible African plants since previous works have reported that application of fertilizers could increase the uptake of the metals ${ }^{40}$.

\section{METHODS}

Eighty-four seedlings of Euphorbia heterophylla, Axonopus compressus, Emilia coccinea and Scoparia dulcis were collected from Awka, State Capital of Anambra State Nigeria. Twenty one seedlings each of Euphorbia heterophylla, Axonopus compressus, Emilia coccinea and Scoparia dulcis were grown on soils isolated in polyethene pots. Twenty each were inoculated, with $20 \mathrm{~cm}^{3}$ of $0.1 \mathrm{M} \mathrm{Cd}\left(\mathrm{NO}_{3}\right)_{2} \cdot 4 \mathrm{H}_{2} \mathrm{O}$ and $\mathrm{Pb}\left(\mathrm{NO}_{3}\right)_{2}$, $\mathrm{Hg}\left(\mathrm{NO}_{3}\right)_{2}, \mathrm{As}_{2} \mathrm{O}_{3}$, buffer 7 , Organic (organic manure) and Inorganic(NPK) fertilizers. $0.1 \mathrm{M} \mathrm{Cd}^{2+}$ and $\mathrm{Pb}^{2+}$ were prepared by the method used by Anarado et al., $2019^{21} .0 .1 \mathrm{M}$ solution of $\mathrm{Hg}\left(\mathrm{NO}_{3}\right)_{2}$ was prepared by dissolving $32.46 \mathrm{~g}$ of mercuric nitrate in a mixture of $5 \mathrm{~mL}$ of nitric acid and $0.5 \mathrm{dm}^{3}$ of distilled water, and diluted with distilled water to $1 \mathrm{dm}^{3} .0 .1 \mathrm{M} \mathrm{As}_{2} \mathrm{O}_{3}$ was prepared by adding water to $19.78 \mathrm{~g}$ of $\mathrm{As}_{2} \mathrm{O}_{3}$, heating mixture close to boiling point and $\mathrm{NaOH}$ crystals were added, while constantly stirring the solution. When dissolved, 2M solution of sulphuric acid was added and the solution made up to $1 \mathrm{dm}^{3}$ with distilled water. Controls were left. Plant parts were harvested after 14 weeks of inoculation. The 
harvested parts were washed, air-dried, ashed at $450^{\circ} \mathrm{C}$, digested with aqua regia and amount of the metal ions concentrations taken up by parts of the plants was done using VARIAN AA240 Atomic
Absorption Spectrophotometer. The $\mathrm{pH}$ of the soil sample was determined with $\mathrm{pH}$ meter.

\section{RESULTS AND DISCUSSIONS}

Table 1: Concentration Of $\mathrm{Pb}^{2+}$ Taken up By The Plants In $\mathrm{mg} / \mathrm{kg}$

\begin{tabular}{ccccccccccccc}
\hline Innoculant & Eh1 & Eh2 & Eh3 & Ac1 & Ac2 & Ec1 & Ec2 & Ec3 & Sd1 & Sd2 & Sd3 \\
\hline P & 0.004 & 0.050 & 0.273 & 0.056 & 0.163 & 0.017 & 0.159 & 0.219 & 0.123 & 0.018 & 0.165 \\
BP & 0.039 & 0.123 & 0.043 & 0.035 & 0.043 & 0.015 & 0.020 & 0.284 & 0.001 & 0.113 & 0.175 \\
BIP & 0.002 & 0.074 & 0.236 & 0.271 & 0.853 & 0.140 & 0.234 & 0.024 & 0.230 & 0.190 & 0.000 \\
BOP & 0.057 & 0.071 & 0.407 & 0.167 & 0.138 & 0.004 & 0.020 & 0.276 & 0.056 & 0.035 & 0.000 \\
IP & 0.099 & 0.008 & 0.115 & 0.021 & 0.267 & 0.016 & 0.000 & 0.125 & 0.023 & 0.106 & 0.000 \\
OP & 0.024 & 0.020 & 0.167 & 0.263 & 0.203 & 0.056 & 0.159 & 0.219 & 0.010 & 0.067 & 0.000 \\
\hline
\end{tabular}

Table 2: Concentration Of $\mathrm{Cd}^{2+}$ Taken up By The Plants $\mathrm{ln} \mathrm{mg} / \mathrm{kg}$

\begin{tabular}{ccccccccccccc}
\hline Innoculant & Eh1 & Eh2 & Eh3 & Ac1 & Ac2 & Ec1 & Ec2 & Ec3 & Sd1 & Sd2 & Sd3 \\
\hline C & 0.057 & 0.268 & 0.026 & 0.200 & 0.390 & 0.098 & 0.269 & 0.650 & 1.521 & 1.331 & 0.843 \\
BC & 0.016 & 0.056 & 0.045 & 0.118 & 0.107 & 0.148 & 0.074 & 0.050 & 0.100 & 0.012 & 0.006 \\
BIC & 0.029 & 0.418 & 0.339 & 3.011 & 1.864 & 3.101 & 2.666 & 1.286 & 0.019 & 0.005 & 0.689 \\
BOC & 0.017 & 0.211 & 1.147 & 1.641 & 0.466 & 0.002 & 0.109 & 0.873 & 0.106 & 0.209 & 0.820 \\
IC & 0.045 & 0.222 & 0.268 & 0.591 & 1.802 & 0.050 & 2.036 & 0.066 & 1.847 & 1.143 & 1.500 \\
OC & 0.019 & 0.351 & 0.297 & 3.021 & 2.326 & 0.025 & 0.035 & 0.258 & 0.083 & 0.711 & 0.003 \\
\hline
\end{tabular}

Table 3: Concentration of $\mathrm{Hg}^{2+}$ Taken up By The Plants In $\mathrm{mg} / \mathbf{k g}$

\begin{tabular}{ccccccccccccc}
\hline Innoculant & Eh1 & Eh2 & Eh3 & Ac1 & Ac2 & Ec1 & Ec2 & Ec3 & Sd1 & Sd2 & Sd3 \\
\hline H & 0.273 & 0.357 & 0.841 & 0.018 & 0.000 & 0.061 & 0.009 & 0.023 & Dd & 0.560 & 0.000 \\
BH & 0.135 & 0.175 & 0.236 & 0.001 & 0.004 & 0.045 & 0.077 & 0.080 & Dd & 0.001 & 0.007 \\
BIH & 0.138 & 0.171 & 0.169 & 0.006 & 0.013 & 0.050 & 0.052 & 0.050 & Dd & 1.302 & 0.000 \\
BOH & 0.113 & 0.169 & 0.122 & 0.019 & 0.011 & 0.050 & 0.077 & 0.065 & Dd & 0.024 & 0.182 \\
IH & 0.096 & 0.136 & 0.098 & 0.002 & 0.005 & 0.020 & 0.056 & 0.080 & Dd & 0.732 & 0.587 \\
OH & 0.092 & 0.116 & 0.127 & 0.015 & 0.001 & 0.030 & 0.050 & 0.087 & Dd & 1.021 & 0.872 \\
\hline
\end{tabular}

Table 4: Concentration of $\mathrm{As}^{3+}$ Taken up By The Plants In mg/kg

\begin{tabular}{cccccccccccc}
\hline Innoculant & Eh1 & Eh2 & Eh3 & Ac1 & Ac2 & Ec1 & Ec2 & Ec3 & Sd1 & Sd2 & Sd3 \\
\hline A & 0.002 & 0.008 & 0.009 & 5.342 & 0.000 & Dd & 11.316 & 13.342 & Dd & 0.981 & 0.201 \\
BA & 0.004 & 0.009 & 0.196 & Dd & Dd & Dd & 5.639 & 10.166 & Dd & 0.005 & 0.002 \\
BIA & 0.005 & 0.007 & 0.027 & Dd & Dd & Dd & 18.340 & 11.130 & Dd & 1.809 & 0.812 \\
BOA & Dd & Dd & Dd & Dd & Dd & Dd & 2.753 & 10.907 & Dd & 0.501 & 1.311 \\
IA & Dd & Dd & Dd & 1.233 & Dd & Dd & 12.241 & 14.232 & Dd & 0.862 & 0.000 \\
OA & 0.014 & 0.019 & 0.015 & Dd & Dd & Dd & 6.817 & 10.913 & Dd & 0.000 & 0.221 \\
\hline
\end{tabular}

$\mathrm{pH}$ of the soil $=6.3$

\section{Codes:}

Eh1, Eh2 and Eh3 = leaf, stem and root of Euphorbia heterophylla respectively.

Ac1 and Ac2 = shoot and root of Axonopus compressus respectively.

Ec1, Ec2 and Ec3 = leaf, stem and root of Emilia coccinea respectively

$\mathrm{Sd} 1, \mathrm{Sd} 2$ and Sd3 = leaf, stem and root of Scoparia dulcis respectively.

$\mathrm{P}=$ lead, $\mathrm{C}=$ Cadmium, $\mathrm{A}=$ Arsenic, $\mathrm{H}=$
Mercury, O = Organic fertilizer, I = Inorganic fertilizer.

$\mathrm{Dd}=$ Died.

The results of the analyses showed that generally, the order of the metal ions absorption by the four plants follows the order; $\mathrm{As}>\mathrm{Cd}>\mathrm{Hg}>\mathrm{Pb}$. Euphorbia heterophylla absorbed more of Cadmium and Mercury relative to Lead and Arsenic in the order; cadmium>mercury>lead>arsenic. Inorganic 
fertilizer application decreased the absorption of $\mathrm{Pb}^{2+}$ by Euphorbia heterophylla both at $\mathrm{pH}$ of 6.3 and 7 which was against the report of Chu et al., 2018 that organic and inorganic fertilizer applications increased lead absorption by Polygonum hydropiper $\mathrm{L}^{41}$, Also organic manure application increased the absorption of the $\mathrm{Pb}^{2+}$ only in neutral condition $(B P-B O P=0.205 \mathrm{mg} / \mathrm{kg}-0.532 \mathrm{mg} / \mathrm{kg})$. Since the roots absorbed most of the metal ion except in BP, both organic and inorganic fertilizers can strengthen phytostabilization rate of $E$. heterophylla to $\mathrm{Pb}$, this is in line with the reports Mendes et al., $2006^{40}$, also that phytostabilization technique was good in remediating $\mathrm{Pb}$ from the soil ${ }^{5}$. The reduction of lead concentration absorbed by the plant when the $\mathrm{pH}$ was increased from 6.3 to 7 was in line with the report of Traunfeld and Clement, $2001^{42}$. Axonopus compressus, absorbed cadmium and arsenic relative to lead and mercury. Inorganic and organic fertilizer applications in $A$. compressus increased the uptake of lead ion both in acidic and neutral mediums. Those plants inoculated with inorganic fertilizers showed the absorption of the metal ion more in shoot regions, showing the inorganic fertilizers can strengthen the phytoextraction rate of the plant while organic fertilizer application can enhance the phytostabilization rate of the metal ion by the plant since most were absorbed in root. Emilia coccinea generally absorbed $\mathrm{As}^{3+}$ and $\mathrm{Cd}^{2+}$ relative to $\mathrm{Pb}^{2+}$ and $\mathrm{Hg}^{2+}$. Application of inorganic fertilizer in neutral condition increased the absorption of lead, but decreased the absorption of lead in acidic condition. Fertilizer application enhanced phytostabilization of the metal ion by the plant since most of the ions were found in the roots. Scoparia dulcis absorbed more cadmium and arsenic relative to mercury and lead. Application of NPK fertilizer at $\mathrm{pH}$ of both 6.3 and 7 increased the absorption of lead by S. dulcis, but application of organic manure decreased the absorption. Increase in the $\mathrm{pH}$ decreased the absorption in line with Traunfeld and Clement, $2001^{42}$. Generally the order of lead absorption by all the plants is as follows; $\mathrm{Ac}>\mathrm{Ec}>\mathrm{Eh}>\mathrm{Sd}$. The order of absorption of $\mathrm{Cd}^{2+}$ by the plants is as follows; Ac $>\mathrm{Ec}>\mathrm{Sd}>\mathrm{Eh}$. Application of both organic and inorganic fertilizers increased the absorption of $\mathrm{Cd}^{2+}$ by $E$. heterophylla both at $\mathrm{pH}$ of 6.3 and 7-This is in line with the reports of Sampanpanish and Wanapan, 2016 and Roberts, 2014 which stated that concentrations of $\mathrm{Cd}$ were found to increase when the application rate of fertilizer increased and fertilization increases the risk of $\mathrm{Cd}$ movement into the food chain ${ }^{43,44}$, most absorption occurred when organic manure was applied at $\mathrm{pH}$ of $7(1.375 \mathrm{mg} / \mathrm{kg})$ This is in line with report of Grant and Sheppard, 2008 that higher soil organic matter content will increase $\mathrm{Cd}$ adsorption ${ }^{45}$. Application of organic fertilizer at $\mathrm{pH}$ of 7 strengthened phytostabilization rate of $E$. heterophylla. Application of inorganic fertilizer at $\mathrm{pH}$ of 6.3 strengthened the phytostabilization rate of the plant. Application of both organic and inorganic fertilizers increased the absorption of $\mathrm{Cd}^{2+}$ by $A$. compressus. Absorption occurred most when inoculated with organic fertilizer at $\mathrm{pH}$ of 6.3 (total $=5.347 \mathrm{mg} / \mathrm{kg}$ ). Application of organic manure enhanced phytoextraction of the metal ion at both $\mathrm{pH}$ of 6.3 and 7. Increase in the $\mathrm{pH}$ decreased the absorption of the ion-this is in line with the findings of Hattori et al., 2006 which stated that decrease in $\mathrm{pH}$ increased the absorption of $\mathrm{Cd}^{46}$. Generally application of fertilizers decreased the absorption of $\mathrm{Cd}^{2+}$ by Emilia coccinea except with inorganic fertilizer at $\mathrm{pH}$ of 7 . Also application of both fertilizers increased the absorption of cadmium, absorption was most when inorganic fertilizer was applied in neutral condition $(7.053 \mathrm{mg} / \mathrm{kg}$ )- This could be as result of Phosphorous fertilizer being the major anthropogenic source of $\mathrm{Cd}^{45}$. Increase in $\mathrm{pH}$ increased absorption. Application of inorganic fertilizer at both $\mathrm{pH}$ enhanced phytoextraction while application of organic fertilizer at $\mathrm{pH}$ of 7 enhanced phytostabilization. Scoparia dulcis absorbed most $\mathrm{Cd}^{2+}$ when inorganic fertilizer was applied at $\mathrm{pH}$ of 6.3 (total $=4.422 \mathrm{mg} / \mathrm{kg}$ ). Application of inorganic fertilizer at both $\mathrm{pH}$ increased the uptake of the metal ion by the plant, but only increased with organic fertilizer at $\mathrm{pH}$ of 7 . Acidic condition strengthened phytoextraction. Increase in $\mathrm{pH}$ decreased the absorption of $\mathrm{Hg}^{2+}$ by E. heterophylla, A. compressus, S. dulcis, but increased the absorption with E. coccinea. Application of both organic and inorganic fertilizers decreased the absorption of $\mathrm{Hg}^{2+}$ by $E$. heterophylla, E. coccinea and $A$. compressus (when inoculated at $\mathrm{pH}$ of 6.3)- This is against the findings of Atafar et al., 2010 ${ }^{31}$. Application of the both fertilizers increased the absorption of the metal ion by $\mathrm{S}$. dulcis and $A$. compressus (when inoculated at $\mathrm{pH}$ of 7 ). Increase in $\mathrm{pH}$ decreased the absorption of $\mathrm{As}^{3+}$ with S. dulcis and E. coccinea and $A$. compressus, but increased absorption of the ion with E. heterophylla, E. coccinea showed a very good phytoremediating potential against $\mathrm{As}^{3+}$, it 
could be regarded as an arsenic hyperaccumulator. Though there were abscissions of the leaves of E. coccinea and S. dulcis. It was not supprising to see that As inoculation resulted in phytotoxicity of some parts of all the plants used which is in line with the report of Kim, 2019 that As is phytotoxic ${ }^{47}$. Highest absorption of arsenic by E. coccinea was observed on addition of inorganic fertilizers at $\mathrm{pH}$ of 7 (total $=29.510 \mathrm{mg} / \mathrm{kg}$ ) and 6.3 (total $=26.473 \mathrm{mg} /$ $\mathrm{kg}$ ) which is against the report of Pigna et al., 2010 that $P$. fertilization prevented As uptake ${ }^{48}$. Application of NPK fertilizer increased the absorption of As at both $\mathrm{pH}$ with $E$. coccinea, at only $\mathrm{pH}$ of 7 with S. dulcis. Application of organic manure decreased the absorption of ion at both $\mathrm{pH}$ with E. coccinea, increased absorption at $\mathrm{pH}$ of 6.3 with E. heterophylla and at $\mathrm{pH}$ of 7 with $\mathrm{S}$. dulcis.

\section{CONCLUSION}

Heavy metal pollution of environment has been increasing with increase in industrialization and urbanization. Phytoremediation being green and inexpensive technique, capable of cleaning up of these metals from the environment was employed in this research. From this work, it could be concluded that application of fertilizers affected the metals' uptake by the plants used. Though As was phytotoxic at some $\mathrm{pH}$ to some parts, E. coccinea showed very good phytoremediating potential against $A$ s and so could be used in an environment polluted by $\mathrm{As}^{3+}$.

\section{ACKNOWLEDGEMENT}

We acknowledge the Nnamdi Azikiwe University Central Laboratory for providing the facilities for this research. We also thank the Botany Department of Nnamdi Azikiwe University for assisting in the plants' identification.

\section{Conflict of Interest}

We wish to state that there is no conflict of interests in this work.

\section{REFERENCES}

1. Kelishadi, R. Environmental Pollution: Health Effects and Operational Implications for Pollutants Removal. Journal of Environmental and Public Health., 2012, https://doi.org/ 10.1155/2012/341637.

2. Skenderovic, I.; Kalac, B.; Becirovic, S. Environmental pollution and waste Management. Balkan Journal of Health Science., 2015, 3(1), 1-10.

3. Oh, K.; Cao, T.; Li, T. and Cheng, H. Study on Application of Phytoremediation Technology in Management and Remediation of Contaminated Soils. Journal of Clean Energy Technologies., 2014, 2(3), 216-220. DOI: 10.7763/JOCET.2014.V2.126.

4. Manaf, F. A. and Santy, S. K. A Study on the Effect of chemical Remediation and Phytoremediation on Soils Contaminated by Hospital Waste, Chemical Fertilizers and Slurry Waste. International Journal of Engineering Research \& Technology., 2017, 6(02), 614618. DOI: $10.17577 / I J E R T V$ 6IS020352.

5. Wuana, R.A. and Okieimen, F.E. "Heavy Metals in Contaminated Soils: A Review of Sources, Chemistry, Risks and Best Available Strategies for Remediation," ISRN Ecology., 2011, 20, https://doi.org/10.5402/2011/402647.

6. Jaishankar, M.; Tseten, T.; Anbalagan, N.;
Mathew, B. B. and Beeregowda, K. N. Toxicity, mechanism and health effects of some heavy metals. Interdisciplinary Toxicology., 2014, 7(2), 60-72.

7. Duruibe, J. O.; Ogwuegbu, M. O. C. and Egwurugwu, J. N. Heavy metal pollution and human biotoxic effects. International Journal of Physical Sciences., 2007, 2(5), 112-118.

8. Gaur, A. and Adholeya, A. "Prospects of arbuscular mycorrhizal fungi in phytoremediation of heavy metal contaminated soils," Current Science, 2004, 86(4), 528-534.

9. Zhang, X.; Zhong, T.; Liu, L.; Ouyang, X. Impact of Soil Heavy Metal Pollution on Food Safety in China. PLoS ONE., 2015, 10(8), e0135182. https://doi.org/10.1371/journal.pone.0135182.

10. Linacre N.A.; Whiting, S.N. \& Angle, J.S. The Impact of Uncertainty on Phytoremediation Project Costs. International Journal of Phytoremediation., 2005, 7(4), 259-269.https:// doi.org/10.1080/16226510500327103.

11. Anarado, C.J.O.; Anarado, C.E.; Areh, R.I.; Ifoh, N.; Eze, E.O.; Ikeakor, E. lodine Fortification Study of Some Common African Vegetables. Journal of Agricultural Chemistry and Environment., 2019, 8, 172-183. https:// doi.org/10.4236/jacen.2019.83014. 
12. Kiferle, C.; Gonzali, S. and Holwerda, H.T. Tomato Fruits: A Good Target for lodine Biofortification. Frontiers in Plant Science., 2013, 27, 205. https:// doi.org/10.3389/fpls. 2013.00205.

13. Landini, M.; Gonzali, S. and Pierdomenico Perata, P. lodine biofortification in tomato. J. Plant Nutr. Soil Sci., 2011, 174, 480-486. DOI: 10.1002/jpln.201000395

14. Otaru, A.J.; Ameh, C.U.; Okafor, J.O.; Odigure, J.O.; Abdulkareem, A.S. and Ibrahim, S. Study on the Effectiveness of Phytoremediation in the Removal of Heavy Metals from Soil Using Corn, International Journal of Computational Engineering Research., 2013, 03(4), 87-93.

15. Rai, P. K. Heavy Metal Pollution in Aquatic Ecosystems and its Phytoremediation using Wetland Plants: An ecosustainable approach. International Journal of Phytoremediation, 2008, 10(2), 133-160. https://doi.org/10.1080/ 15226510801913918.

16. Rahman, A. H.; Hasegawa, M. Aquatic arsenic: Phytoremediation using floating macrophytes. Journal of Chemosphere., 2011 83(5), 633-646. https://doi.org/10.1016/j. chemosphere.2011.02.045.

17. Vishnoi, S. R. and Srivaslava, P.N. Phytoremediation- Green for Environmental clean. The $12^{\text {th }}$ World lake conference., 2008 , 1016-1021.

18. Bolan, N.; Park, J. H.; Robinson, B.; Naidu, R.; Huh, K.Y. Phytostabilization. Advances in Agronomy., 2011, 112, 145-204. DOI: 10.1016/B978-0-12-385538-1.00004-4.

19. Zadeh, B.M.; Savaghebi-Firozabadi, G.R.; Hossein Ali Alikhani, H. A. and Hosseini, H. M. Effect of Sunflower and Amaranthus Culture and Application of Inoculants on Phytoremediation of the Soils Contaminated with Cadmium. American-Eurasian J. Agric. \& Environ. Sci., 2008, 4(1), 93-103.

20. Bieby, V.T.; Siti, R. S. A.; Hassan B.; Mushrifah, I.; Nurina, A. and Muhammad, M. A Review on HeavyMetals (As, $\mathrm{Pb}$, and $\mathrm{Hg}$ ) Uptake by Plants through Phytoremediation. International Journal of Chemical Engineering., 2011, doi: 10.1155/2011/939161.

21. Anarado, C. E.; Anarado, C. J. O.; Okeke, M.O.; Ezeh, C.E.; Umedum, N.L. and Okafor, P.C. Leafy Vegetables as Potential Pathways to Heavy Metal Hazards. Journal of Agricultural Chemistry and Environment., 2019, 8, 23-32. https://doi.org/10.4236/ jacen.2019.81003.

22. Anarado, C.E.; Mmeka, O.P.; Anarado, C.J.O. and Umedum, N.L. Phytoremediation
Potentials of Dieffenbachia bownanii and Eleusine indica for Cadmium, Lead, Zinc and Cobalt. IOSR Journal of Applied Chemistry (IOSR-JAC)., 2018, 11(7), 68-71. DOI: 10.9790/5736-1107026871

23. Anarado, C.E.; Anarado, C.J.O.; Agwuna, C.; Okeke, M.O.; Okafor, P.C. Phytoremediating Potentials of Sida acuta and Duranta erecta for Lead, Cadmium, Cobalt and Zinc. International Journal of Science and Research(IJSR)., 2018, 7(11), 969-971. DOI: 10.21275/ART20192715.

24. Anarado, C.E.; Anarado, C.J.; Egwuatu, C.I.; Umedum, N.L.; Okoye, P.A.C. Phytoremediation of Cobalt, Lead and Zinc Using Selected African Plants. AASCIT Communications., 2016, 3(5), 212-216.

25. Anarado, C.E.; Anarado, C.J.O.; Anyaegbu, E.C.; Umedum, N.L. and Chukwuma, V.D. Comparative Study Of The Phytoremediating Potentials Of Pennistum purpureum and Axonopus fissifolius Against $\mathrm{Pb}^{2+}, \mathrm{Cd}^{2+}, \mathrm{Zn}^{2+}$ and $\mathrm{Co}^{2+}$. J. Chem Soc. Nigeria., 2020, 45(2), 275-281.

26. Mojiri, A.; Aziz, H.A.; Zahed, M.A.; Aziz, S.Q.; Selamat, M. R. B. Phytoremediation of Heavy Metals from Urban Waste Leachate by Southern Cattail (Typha domingensis). International Journal of Scientific Research in Environmental Sciences(IJSRES)., 2013, 1(4), 63-70. DOI: 10.12983/ijsres-2013-p063-070.

27. Holmgren, G.G.S.; Meyer, M.W.; Chaney, R.L. and Daniels, R.B. Cadmium, Lead, Zinc, Copper, and Nickel in Agricultural Soils of the United States of America. Journal of Environmental Quality Abstract., 1993, 22(2), 335-348. DOI: 10.2134/jeq1993. $00472425002200020015 x$

28. Kavitha, K. K. and Jegadeesan, M. Mercury and cadmium accumulation in selected weed plants: Implications for phytoremediation. Asian Journal of Plant Science and Research., 2014, 4(5), 1-4.

29. Sallami, K.; Coupe, S.J.; Rollason, J.; Ganjian, E. Soil amendments to enhance lead uptake by Eucalyptus camaldeulensis cultivated on metal contaminated soil. European Journal of Experimental Biology., 2013, 3(6), 7-13.

30. Huang, S.; Jin, J. Status of heavy metals in agricultural soils as affected by different patterns of land use. Environ Monit Assess., 2008, 139, 317. https://doi.org/10.1007/ s10661-007-9838-4 
31. Atafar, Z.; Mesdaghinia, A.; Nouri, J.; Homaee, M.; Yunesian, M.; Ahmadimoghaddam, M.; Amir Hossein Mahvi, A.H. Effect of fertilizer application on soil heavy metal concentration. Environ Monit Assess., 2010, 160(1-4), 83-89. https://doi.org/10.1007/s10661-008-0659-x.

32. Li, T.; Cheng, H.; Oh, K. and Hosono, S. Effect of Humic Acid and Bacterial Manure on Distribution of Heavy Metals in Different Organs of Maize. International Journal of Environmental Science and Development., 2014, 5(4), 393-397.

33. Chen, H., Cutright, T.J. The interactive effects of chelator, fertilizer and rhizobacteria for enhancing phytoremediation of heavy metal contaminated soil. Journal of Soils and Sediments., 2002, 2(4), 203-210. https://doi. org/10.1007/BF02991040.

34. Wei, S.; Li, Y.; Zhou, Q.; Srivastava, M.; Chiu, S.; Zhan, J.; Wu, Z.; Sun, T. Effect of fertilizer amendments on phytoremediation of Cd-contaminated soil by a newly discovered hyperaccumulator Solanum nigrum L. Journal of Hazardous Materials., 2010, 176(1-3), 361366. DOI: 10.1016/j.jhazmat.2009.11.023.

35. Shtangeeva, I.; Luiho, J.V.; Kahelin, H. \& Gobran, G.R. Improvement of phytoremediation effects with help of different fertilizer. Journal of Soil Science and Plant Nutrition., 2004, 50(6). https:// doi.org/10.1080/00380768.2004.10408550.

36. Guo, J.; Lei, M.; Yang, J.; Yang, J.; Wan, X.; Chen, T.; Zhou, X.; Gu, S.; Guo, G. Effect of fertilizers on the $\mathrm{Cd}$ uptake of two sedum species (Sedum spectabile Boreau and Sedum aizoon L.) as potential Cd accumulators. Journal of Ecological Engineering., 2017, 106, Part A, 409-414. https://doi.org/10.1016/j. ecoleng.2017.04.069.

37. Liu, Y.; Zhuang, P.; Li, Z.; Zou, B.;Wang, G.; Li, N.; Qiu, J. Effects of Fertiliser and intercropping on cadmium uptake by maize. Chemistry and Ecology., 2013, 29(6), 489-500. https://doi. org/10.1080/02757540.2013. 810720.

38. Li, N.Y.; Fu, Q. L.; Zhuang, P.; Guo, B.; Zou, B. \& Li, Z.A. Effect of Fertilizers on Cd Uptake of Amaranthus hypochondriacus, a High Biomass, Fast Growing and Easily Cultivated Potential Cd Hyperaccumulator. International Journal of Phytoremediation., 2011, 4(2), 162-173. https:// doi.org/10.1080/15226514.2011.587479.

39. Rotkittikhun, P.; Chaiyarat R.; Kruatrachue, M.; Pokethitiyook, P.; Baker, A.J.M. Growth and lead accumulation by the grasses Vetiveria zizanioides and Thysanolaena maxima in lead-contaminated soil amended with pig manure and fertilizer: A glasshouse study.
Journal Of Chemosphere., 2007, 66(1), 45-53. DOI: 10.1016/j.chemosphere.2006.05.038.

40. Mendes, A.M.S.; Duda, G.P.; do Nascimento, C.W.A.; Silva, M.O. Bioavailability of cadmium and lead in a soil Amended with phosphorus fertilizers. Sci. agric. (Piracicaba, Braz.). 2006, 63(4). https://doi.org/10.1590/S010390162006000400003.

41. Chu, H.; Hanh, N.P.; Hien, N.T.; Tu, V.V. Effect of fertilizer on lead $(\mathrm{Pb})$ accumulation ability of Polygonum hydropiperL. J. Viet. Env., 2018, 9(2), 67-72 DOI: 10.13141/jve.vol9.no2.pp67-72

42. Traunfeld, J. H. and Clement, D. L. "Lead in Garden Soils. Home and Garden," Maryland Cooperative Extention, University of Maryland. 2001.http://www.hgic.umd.edu/_media/ documents/hg18.pdf.

43. Sampanpanish, P. and Wanapan, P. Effect of Chemical Fertilizer on Cadmium Uptake by Sugarcane Grown in Contaminated Soil. International Journal of Agricultural Research., 2016, 11, 126-134. https://scialert. net/abstract/?doi=ijar.2016.126.134.

44. Roberts, T.L. Cadmium and Phosphorous Fertilizers: The Issues and the Science. "SYMPHOS 2013", $2^{\text {nd }}$ International Symposium on Innovation and Technology in the Phosphate Industry. Procedia Engineering., 2014, 83, 52-59. Doi: 10.1016/j. proeng.2014.09.012.

45. Grant, C.A. and Sheppard, S.C. Fertilizer Impacts on Cadmium Availability in Agricultural Soils andCrops',Human and Ecological Risk Assessment: An International Journal., 2008, 14(2), 210-228. http://dx.doi. org/10.1080/10807030801934895.

46. Hattori, H.; Kuniyasu, K.; Chiba, K. \& Chino, M. Effect of chloride application and low soil $\mathrm{pH}$ on cadmium uptake from soil by plants. Soil Science and Plant Nutrition., 2006, 52(1),89-94. https://doi.org/10.1111/j.17470765.2006.00007.x

47. Kim, M-S.; Min, H-G., Kim, J-G. and Lee, S-R. Estimating Arsenic Mobility and Phytotoxicity Using Two Different Phosphorous fertilizer Release Rates in Soil. Agronomy., 2019, 9(111), 1-13. doi:10.3390/ agronomy 9030111.

48. Pigna, M.; Cozzolino, V.; Caporale, A.G.; Mora, M.L.; Meo, V.D.; Jara, A.A. and Violante, A. Effects Of Phosphorus Fertilization On Arsenic Uptake By Wheat Grown In Polluted Soils. Journal of soil science and plant nutrition., 2010, 10(4), 428-442. http://dx.doi. org/10.4067/S0718-95162010000200004. 